\title{
Bite characteristics of wapiti (Cervus elaphus) in seasonal Bromus-Poa swards
}

\author{
ZHIGANG JIANG AND ROBERT J. HUDSON
}

\begin{abstract}
The first author was Ph.D. candidate, now post-doctoral fellow, the second author is professor of wildlife productivity and management, Department of Animal Science, Univ. Alberta, Edmonton, Alberta, Canada, T6G 2 P5.
\end{abstract}

\begin{abstract}
We used a cubic sampling quadrat to study the 3-dimensional structure of volunteer Bromus-Poa swards, and explored the relationship of bite depth and sward height as a determinant of bite sizes of wapiti (Cervus elaphus) in the mixed-wood parklands of central Alberta, Canada. The vertical biomass distribution of the sward was pyramidal with leaves dominating the top stratum. Bite depths of yearling and adult wapiti were not significantly different but both were influenced by sward height and season. Wapiti selected bites in both vertical and horizontal dimensions. In spring, wapiti selected vertically, taking green leaves in the top layer of the sward. They selected forbs horizontally in summer and selected leaves vertically in mature autumn swards. Based on the relationships among bite depth and sward height, biomass and sward height, as well as vertical biomass distribution, we calculated expected bite sizes of wapiti on seasonal pasture. We also predicted changes of dietary protein and neutral detergent fiber with increasing bite depth. On spring swards, calculated dietary protein decreased and fiber increased as animals grazed deeper into the swards. In summer and autumn, dietary protein peaked as wapiti cropped about half of the height of the sward whereas dietary fiber was relatively constant. Wapiti adjusted their bite depth to select forage containing at least $14 \%$ protein in spring, summer, and autumn. The sacrifice of bite size in tall summer and autumn swards was compensated by diet quality.
\end{abstract}

Key Words: elk, bite depth, bite size, sward structure, diet quality, foraging ecology, foraging model

Wapiti (Cervus elaphus) were once abundant throughout western Canada, particularly in the aspen parklands and mixed wood forest. Gates and Hudson (1983) explored the foraging behavior of wapiti with a focus on the habitat selection. Hudson and Nietfeld (1985) and Hudson and Watkins (1986) studied feeding rate of wapiti in relation to forage biomass. Both studies indicated that sward structure was an important determinant of foraging behavior of wapiti.

Sward structure influences the forage behavior of herbivores (Milne et al. 1982, Barthram and Grant 1984). Domestic grazers consume more green than cured matter and more leaves than stems (Arnold 1987, Black and Kenney 1984, Dudzinski and Arnold 1973). Grazing sheep adjust their bite stratum according to sward structure (Burlison et al. 1991). Sward height in homogeneous hand-constructed swards has the most influence on bite depth (Ungar et al. 1991). Tiller length is correlated with herbage availa-

\footnotetext{
The authors thank the Natural Science and Engineering Research Council, Alberta Agricultural Research Institute (Farming for the Future), and the Canadian Circumpolar Institute for financial support; Mr. C.D. Olsen for logistic support; Ms. P.I. Marceau for lab assistance; and Dr. D.E. Spalinger and 2 anonymous reviewers for helpful comments on drafts of the manuscript.

Manuscript accepted 12 Jun 1993.
}

bility which in turn is correlated with bite size and forage intake (Allen and Whittaker 1970, Forbes 1989, Ungar et al. 1991).

$A$ bite is the basic unit of diet selectivity by herbivores and it forms the basis of several grazing models (Demment and Greenwood 1988, Ungar and Noy-Meir 1988). Unfortunately, bite size and food intake are difficult to quantify. Stobbs (1973a) and Milne (1982) used esophageal fistulation and Allden and Whittaker (1970) employed short-term weight gain during grazing. Other approaches include hand-plucked samples (Hudson and Nietfeld 1985), artificial swards (Demment and Greenwood 1988, Spalinger et al. 1988 Ungar, and Noy-Meir 1988), and marker methods (Holleman and White 1989, Jiang and Hudson 1992).

In this study, we assessed bite size and diet quality of wapiti in relation to bite depth in seasonal Bromus-Poa swards with different vertical biomass and quality profiles. Specific questions guiding our study were (1) how do stratification of sward biomass and forage quality change seasonally? and (2) how do wapiti adjust bite selection in relation to these changes in sward structure? From this, we inferred how bite depth affected bite size and diet quality. Bite depths generally were linearly related to sward height. Wapiti adjusted their bite depth to ingest food with a lower protein limit of about $14 \%$ in spring, summer, and autumn. Wapiti took large bites in tall swards in spring and took unexpectedly small bites in tall cured swards in autumn.

\section{Methods}

\section{Study Area and Animals}

The study was conducted at the Ministik Wildlife Research Station, near Edmonton, Alberta, Canada. The study area exhibits a cool, continental climate characterized by short, warm summers and long, cold winters (Wonders 1969). The major vegetation types are Populus forest, Bromus-Poa pasture, and Carex wetland (Gates and Hudson 1983). Grasses (Bromus pumpelliamus (Scribn.) Wagnon, Poa pratensis L.) flushed in May. Green graminoid leaves dominated the sward canopy in mid-May. Inflorescences appeared in late May and seeds ripened in August. The dominant dicot, dandelion ( Taraxacum officinale Weber), emerged in early May, became the most visible dicot in early June, and persisted to autumn. Following dandelion, clovers (Trifolium spp.) reached their peak biomass in July and survived until the end of the frost-free period. Other dicots like Achillea millefolium L., Aster spp., Cirsium arvense (L.) Scop., and Fragaria virginiana Duchesne spp. glauca (S. Watts) Staudt comprised less than $1 \%$ of the pasture biomass.

We studied 12 female wapiti, 6 born in 1988 for the 1990 grazing season and another 6 born in 1990 for the 1991 grazing season (denoted sub-adults and yearlings, respectively). Half of the subadults and 2 of the yearlings were hand-reared, facilitating close observation. In May 1990, the sub-adults weighed $230 \pm 7 \mathrm{~kg}$. In 

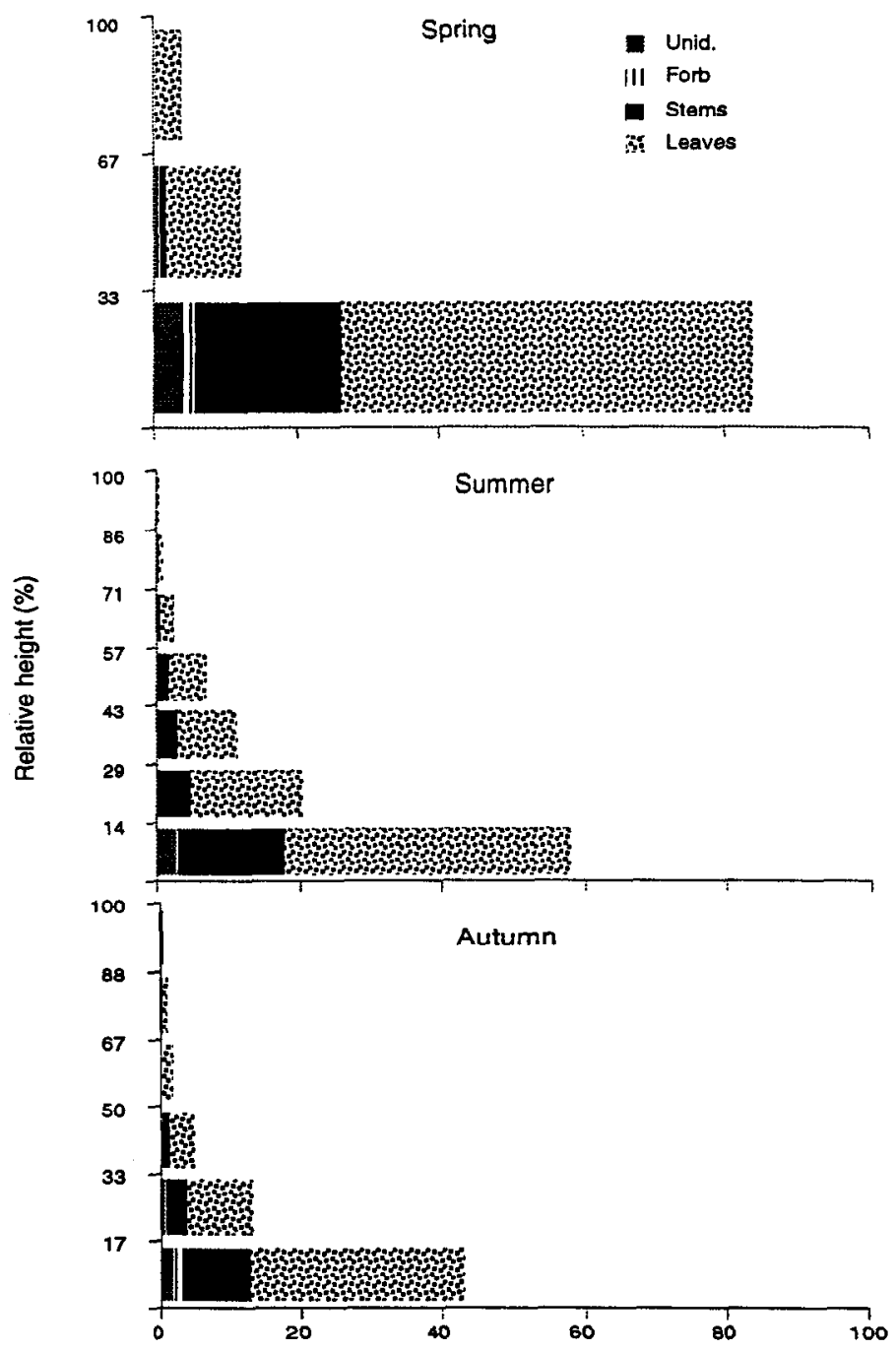

Relative Biomass (\%)

Fig. 1. Seasonal sward structure and composition. Vertically, the biomass distribution in swards was a pyramidal structure. In spring, the biomass pyramid had a relatively larger base and there were more green leaves in the top layer. Transposing axes and calculating median RB and RH (Equations 1 and 2), the relationship between biomass and height can be summarized by the following equations: spring, $R B=4.5( \pm 1.45)$ $\exp (-0.043( \pm .006) \mathrm{RH})\left(r^{2}=0.98\right) ;$ summer, $\mathrm{RB}=5.3( \pm 1.27) \exp$ $-0.057( \pm 0.004) R H)\left(r^{2}=0.96\right) ;$ autumn, $R B=5.5( \pm 1.06) \exp$ $-0.056( \pm 003) R H)\left(r^{2}=0.98\right)$.

May 1991, the yearlings weighed $138 \pm 7 \mathrm{~kg}$.

\section{Sward Structure and Bite Characteristics}

We studied sward structure with a cubic sampling quadrat. The quadrat had 3 stacked $0.5 \times 0.5-\mathrm{m}$ frames welded with 4 steel wires ( $1 \mathrm{~m}$ long and $5 \mathrm{~mm}$ in diameter) at the 4 corners. Between the top and bottom, a movable frame was adjusted to specific heights and fixed by wing-nuts. Two $1-\mathrm{m}$ rulers were welded at opposing sides to measure the height of the movable quadrat. With this device, we sampled 9 quadrats per season in the experiment paddock in late May (fully leafed stage, late spring), late June and early July (full bloom stage, summer) and August (seed ripened stage, autumn), respectively, in 1990. In spring, we cut the swards into 3 layers of equal height, whereas in summer and autumn we cut 7 and 6 layers, respectively. We separated the sample into graminoid stems, graminoid leaves, dicots, and unidentified portions. In spring, we also sorted the sample into green and cured matter. We clipped another ten $0.5 \times 0.5-\mathrm{m}$ samples (without distinguishing layers) in each season to increase the sample size for studying the relationship of sward height and biomass. For the additional samples, we averaged the sward height at the 4 corners of the quadrat. From mid-May till mid-October, 1990 , we randomly measured 22 plant heights every 10 days.

We subsequently assessed bite depth and bite area and observed the experimental animals. On dew, frost, or newly grazed swards, we measured bite imprints to calculate bite areas (Jiang and Hudson 1993). The bite imprints were measured along the long axis and short axis and the bite area was calculated as an ellipse. In each season, we assumed that bite areas of the same age group were similar. We opportunistically measured the stubble heights of 50 bites and 50 adjacent ungrazed plants in the vicinity of the bites and calculated the difference as bite depth. Vertical diet selection in spring was determined in May 1990. Wapiti were released into a previously ungrazed paddock. We measured the height of dried plants, green grass, and bite stubble.

\section{Forage Quality}

Samples were pooled by layer and season, then oven-dried at $60^{\circ}$ $\mathrm{C}$ for laboratory analysis. Sub-samples were taken for dry matter determination at $110^{\circ} \mathrm{C}$. We determined gross energy, crude protein, neutral detergent fiber (NDF), acid detergent fiber (ADF), and $72 \%$ sulfuric acid lignin. Gross energy was determined with a bomb calorimeter (PARR Instrument Company, Illinois, USA). Crude protein $(\mathrm{N} \times 6.25)$ was determined by the macro-Kjeldahl method (A.O.A.C. 1984). NDF, ADF, and lignin were determined according to Goering and Van Soest (1970).

\section{Calculating Bite Size and Diet Quality}

We calculated relative height (RHi) or relative biomass $(\mathrm{RBi})$ of layer $\mathrm{i}$ in relation to the total height of biomass (Jiang and Xia 1987). We also calculated the median RHi and RBi in each layer, MRHi and MRBi:

$$
\begin{aligned}
& \mathrm{MRH}_{\mathrm{i}}=\frac{\mathrm{RH}_{\mathrm{i}}+\mathrm{RH}_{\mathrm{i}-1}}{2} \quad(\mathrm{i}=1, \ldots, \mathrm{L}) \\
& \mathrm{MRB}_{\mathrm{i}}=\frac{\mathrm{RB}_{\mathrm{i}}}{\mathrm{RH}_{\mathrm{i}}-\mathrm{RH}_{\mathrm{i}-1}} \quad(\mathrm{i}=1, \ldots, \mathrm{L})
\end{aligned}
$$

Table 1. Energy, Protein, NDF, ADF, and lignin in graminoids and dicots.

\begin{tabular}{lrrrcc}
\hline \hline & Energy & Protein & NDF & ADF & Lignin \\
\hline Spring & $(\mathrm{kJ} / \mathrm{g})$ & $(\%)$ & $(\%)$ & $(\%)$ & $(\%)$ \\
C. I. & & & & & \\
C. Culms & $15.8 \pm 0.4$ & $13 \pm 0.2$ & $67 \pm 1$ & $35 \pm 1$ & $8+0.1$ \\
G. Gr'. Leaves & $17.3 \pm 0.3$ & $9 \pm 0.5$ & $76 \pm 1$ & $42 \pm 1$ & $6 \pm 0.1$ \\
G. Gr. Culms & $16.6 \pm 0.2$ & $17 \pm 0.0$ & $51 \pm 2$ & $26 \pm 1$ & $7 \pm 1.0$ \\
G. Dicots & $17.2 \pm 0.0$ & $25 \pm 0.4$ & $30 \pm 1$ & $35 \pm 3$ & $6 \pm 0.4$ \\
Summer & & & & & \\
G. Gr. Leaves & $16.9 \pm 0.0$ & $16 \pm 0.1$ & $65 \pm 2$ & $32 \pm 1$ & $6 \pm 0.2$ \\
G. Gr. Culms & $16.6 \pm 0.2$ & $9 \pm 0.4$ & $75 \pm 1$ & $44 \pm 1$ & $7 \pm 0.1$ \\
G. Dicots & $16.7 \pm 0.0$ & $22 \pm 0.1$ & $33 \pm 1$ & $17 \pm 1$ & $4 \pm 0.0$ \\
Autumn & & & & & \\
G. Gr. Leaves & $16.9 \pm 0.1$ & $16 \pm 0.2$ & $68 \pm 0.09$ & $34 \pm 1$ & $6 \pm 0.1$ \\
G. Gr. Culms & $17.1 \pm 0.1$ & $10 \pm 0.8$ & $75 \pm 0.9$ & $42 \pm 1$ & $7 \pm 0.2$ \\
G. Dicots & $17.0 \pm 0.1$ & $16 \pm 0.1$ & $49 \pm 1.0$ & $29 \pm 1$ & $6 \pm 0.1$ \\
\hline
\end{tabular}

1: C: cured.

2: G: green; Gr: grass.

3: Including heads. 

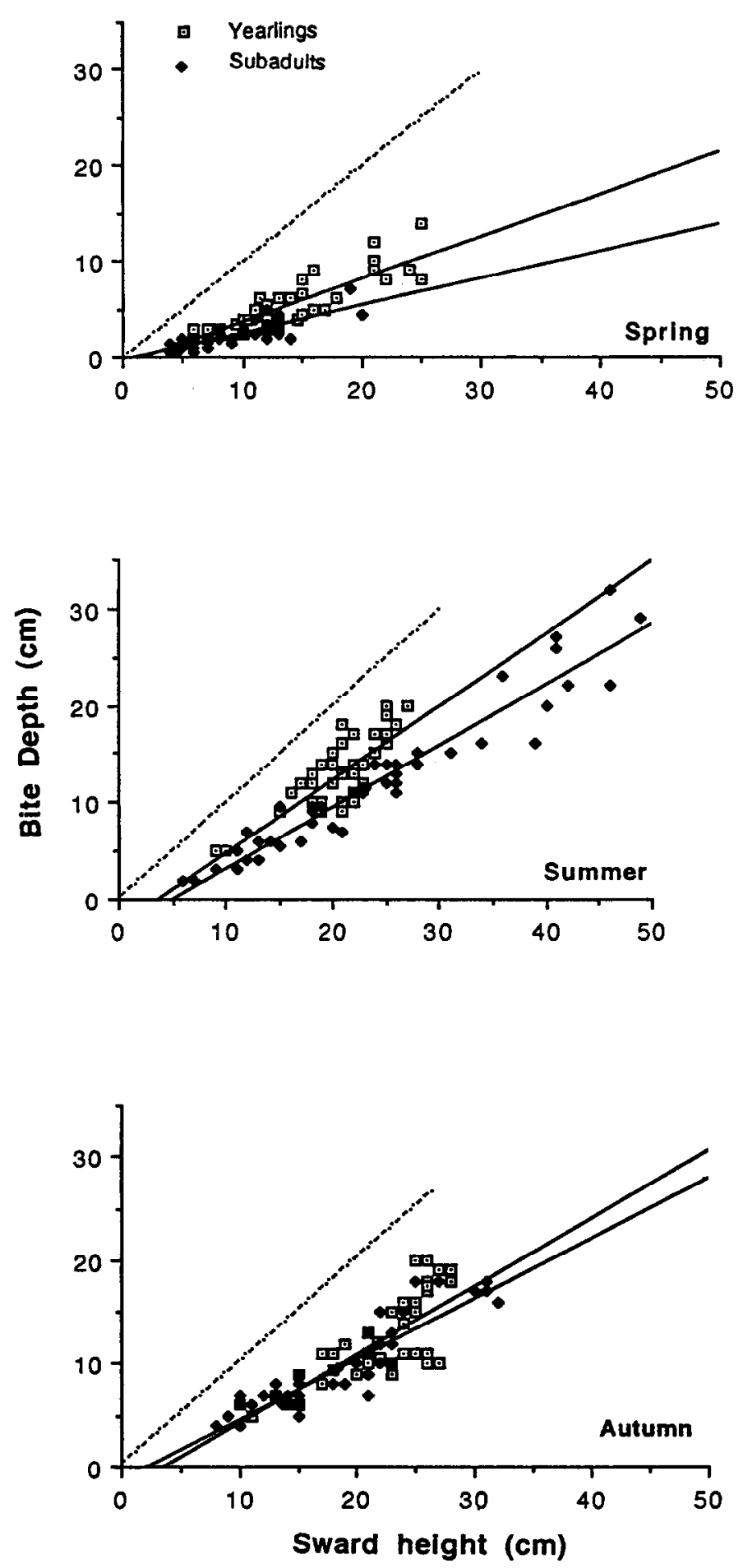

Fig. 2. Bite depths of sub-adult in 1990 and of yearlings in 1991 in seasonal swards. The dotted lines represent the heights of swards. The regressions of bite depth (BD) and sward heights (SH): in spring: $B D=-.61( \pm 0.63)+$ $0.44( \pm 0.04) \mathrm{SH}\left(r^{2}=0.74\right.$, yearlings $)$ and $\mathrm{BD}=-.28( \pm 0.30)+0.29$ $( \pm 0.03) \mathrm{SH}\left(r^{2}=0.61\right.$, sub-adults $)$; in summer: $\mathrm{BD}=-2.6( \pm 1.97)+$ $0.75( \pm 0.09) \mathrm{SH}\left(r^{2}=0.61\right.$, yearlings $)$ and $\mathrm{BD}=-3.05( \pm 0.69)+$ $0.63(0.03)$ SH $\left(r^{2}=0.92\right.$, sub-adults); in autumn: $B D=-2.21( \pm 1.98)+$ $0.66( \pm 0.09) S H\left(r^{2}=0.58\right.$, yearlings $)$ and $\mathrm{BD}=-1.05( \pm 0.83)+0.58$ $( \pm 0.04) \mathrm{SH}\left(r^{2}=0.83\right.$, sub-adults).

Where: $L$ was the number of layers cut in the season, $L=3$ in spring, $L=7$ in summer and $L=6$ in autumn.
Exponential regression between $M R H_{i}$ and $M R B_{i}$ in each season gave a dimensionless biomass density-distribution function along the vertical axis. Bite depth was calculated as an empirical function of sward height. Bite volume is a cylinder with the bite area as the cross-section and bite depth as the height (Ungar and Noy-Meir 1988). Finally, we quantified bite size in relation to bite volume and biomass distribution:

$$
\mathrm{BS}_{(\mathrm{SH}, \mathrm{SN})}=\mathrm{BM}_{(\mathrm{SH}, \mathrm{SN})} \mathrm{BA} \int_{\mathrm{BD} \%(\mathrm{SH}, \mathrm{SN})}^{100} \mathrm{a} \mathrm{e}^{-\mathrm{b} \mathrm{RH}} \mathrm{dRH}
$$

Where: $a$ and $b$ were the exponential regression coefficients, $B S$ was bite size ( $\mathrm{g}), \mathrm{BM}$ was biomass $\left(\mathrm{g} / \mathrm{cm}^{2}\right), \mathrm{BA}$ was bite area $\left(\mathrm{cm}^{2}\right)$, and $\mathrm{SN}$ was season. $\mathrm{BM}_{(\mathrm{SH}, \mathrm{SN})}$ was biomass distribution calculated by logarithmic regression of herbage biomass on sward height in each season. BD\%(SH, $\mathrm{SN}$ ) was the relative bite depth calculated by linear regression of bite depth on sward height in each season.

In Equation (3), the driving variables were sward height and season. Sward height increased at $10-\mathrm{cm}$ intervals from $10 \mathrm{~cm}$ to 30 $\mathrm{cm}$ in spring, to $50 \mathrm{~cm}$ for sub-adults and $40 \mathrm{~cm}$ for yearlings in summer, and to $40 \mathrm{~cm}$ in autumn. The $95 \%$ confidence limits of the bite size was calculated using $95 \%$ confidence limits of the bite depth at specific sward height.

For progressive bite depth, dietary protein and NDF were calculated according to the proportions of green, dead matter, leaf, stem and their respective protein, and NDF contents in each season.

$$
\mathrm{DC}_{(k)}=\sum_{i=1}^{k} \sum_{j=1}^{n} s c_{i j} \cdot p_{j} \quad(k=1, \ldots, L)
$$

Where: $\mathrm{DC}(\mathrm{k})$ was the dietary component such as protein or NDF when bite depth reached the kth layer of the sward. L was the number of layers cut in the season. $\mathrm{sc}_{\mathrm{ij}}$ was the proportion of sward component $j$ such as cured leaves, cured culms, green leaves, green culms, or forbs in the kth layer. $n$ was the number of sward components found in the layer. $p_{j}$ was the percentage of protein or NDF in the sward component $j$. The unidentified portion of the sward sample was pooled with cured stems.

\section{Sod Experiment}

We refined our estimates of bite characteristics using six $0.5 \times$ $0.5-\mathrm{m}$ pieces of sod removed with about $5 \mathrm{~cm}$ of soil layer. We measured the sward heights and placed 1 piece of sod in a pen with 2 hand-reared sub-adult wapiti. When the wapiti started to eat, we took bites from their mouths to determine bite weight and measured the corresponding bite heights. When we placed a finger on the diastema, the animal egested the bite in attempting to remove the finger with her tongue.

\section{Statistics}

Two multivariate analysis of variance (MANOVA) evaluated seasonal and botanical effects and their first order interaction on energy, protein, NDF, ADF, and lignin. A multiple comparison among the means was carried out with the Tukey-Kramer test (Sokal and Rohlf 1981). Because of the different initial sward heights in each season, the impacts of season and cohort on bite depth and their first and second order interactions were explored by 2-way ANCOVA with sward height as a covariate. Data were transformed into their square-roots to achieve homogeneity of variance. Multiple comparisons among the means of sward heights and bite depth were carried out by Fisher's protected LSD method (Sokal and Rohlf 1981). Differences were considered significant where the probability of a type I error did not not exceed 0.05. Data were summarized as the mean \pm 1 se.

\section{Results}

\section{Sward Characteristics}

Biomass in swards was pyramidal, with the greatest bulk density 
at the base of the sward (Fig. 1). Spring swards had more biomass at the bottom $(p<0.05)$. Biomass and height of layers expressed in relative scale were related exponentially $(p<0.05)$. The slope (b) of the exponential regression in spring was significantly different from those in summer and autumn $(p<0.05)$. However, summer swards were no different in vertical biomass distribution from autumn ones $(p>0.05)$.

Protein, NDF, ADF, and lignin differed significantly among seasons $(p<0.05)$ and forages $(p<0.05)$ and the interactions between season and forages were significant $(p<0.05)$. Green matter had more protein and less fiber than cured plant material $(p<0.05$; Table 1). Dicots had more protein and less fiber than graminoids $(p<0.05$; Table 1$)$. Energy content differed significantly among forages but not among seasons $(p<0.05)$.

\section{Bite Characteristics}

Bite depth was affected by season $(p<0.05)$, sward height $(p<0.05)$ and their interaction ( $p<0.05$, Fig. 2). Wapiti grazed deeper in spring swards than in summer and autumn ones $(p<0.05)$. Bite area was related to the age of wapiti. The bite area of sub-adults was $38 \pm 0.1 \mathrm{~cm}^{2}$ in spring, and $49 \pm 0.1 \mathrm{~cm}^{2}$ in summer and autumn of 1990. Bite area of yearlings was $27 \pm 0.03 \mathrm{~cm}^{2}$ in spring and $38 \pm 0.1 \mathrm{~cm}^{2}$ in summer and autumn of 1991 .

In early spring, wapiti selected green leaves above previous year's growth, which set a constraint on diet selection. When the paddock was first grazed, the heights of green grasses were about double that of dried grasses whereas grazed stubble height was about the same as that of dried grasses. The regressions of bite height $(\mathrm{BH})$, green grass height $(\mathrm{GH})$ and dried grass height were as

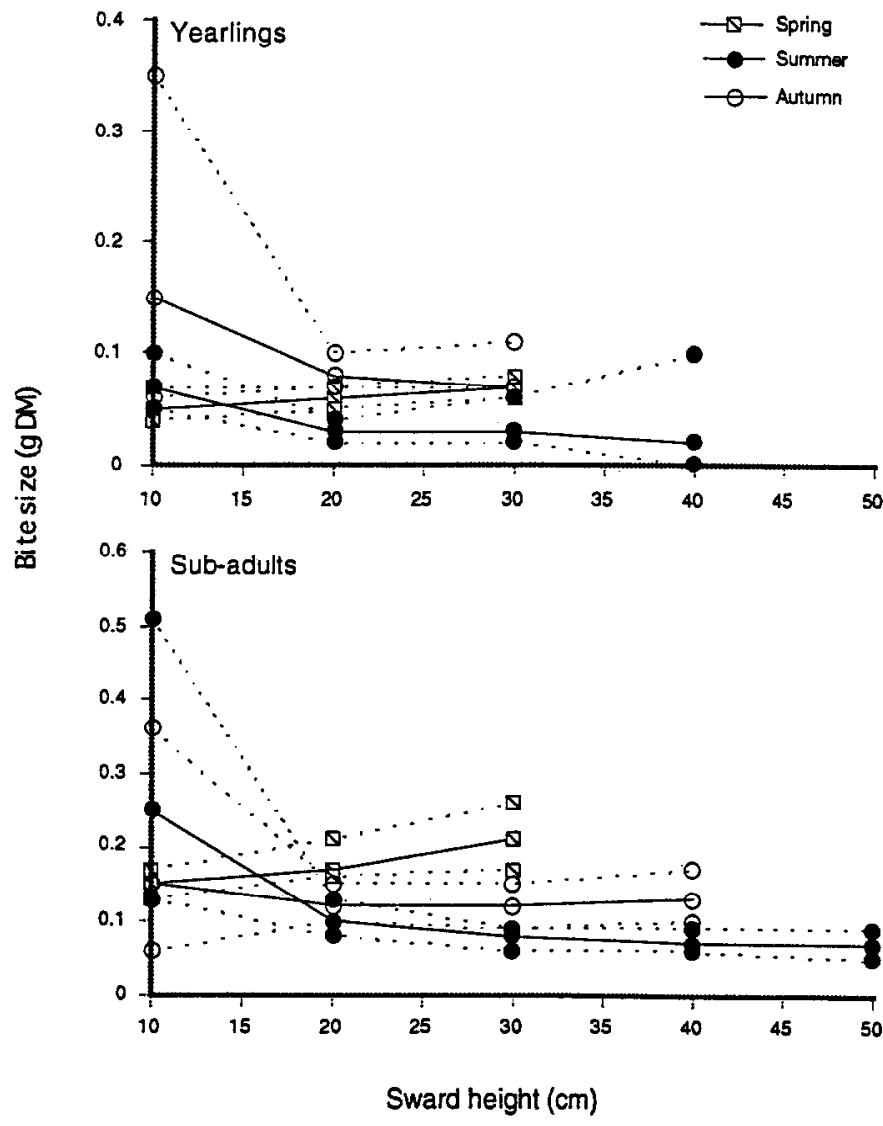

Fig. 3. Simulation of bite size as a function of sward height. The dotted lines are the $95 \%$ confidence limits of the solid lines with the same legend. In spring, wapiti grazed deeper in tall swards; their bite size increased as sward height increased. As the sward matured in summer and autumn, bite size decreased in $20-\mathrm{cm}$ height swards; sward height had little influence on hite size of wapiti when sward height was taller than $20 \mathrm{~cm}$.
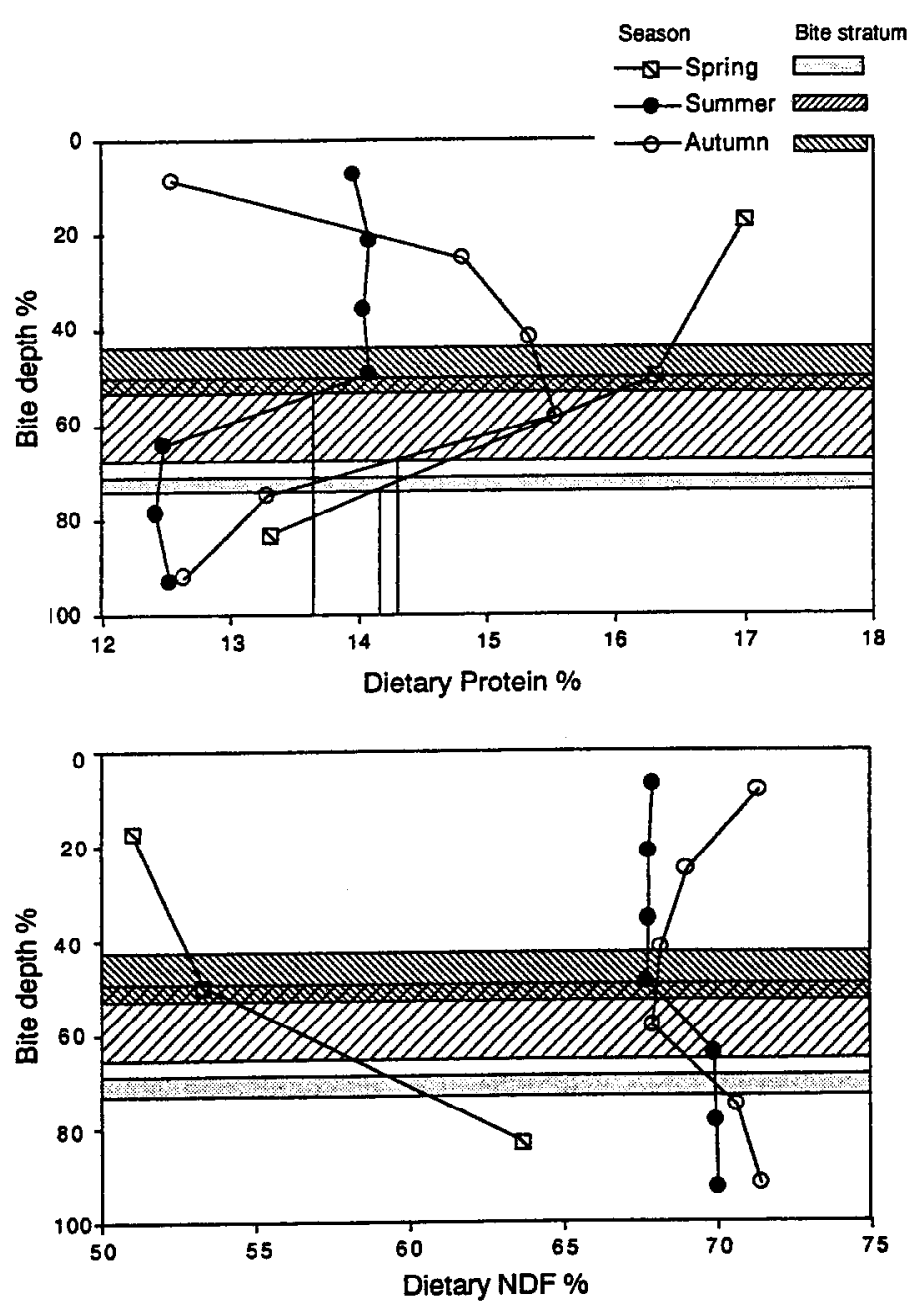

Fig. 4. Bite strata in each season (range of mean bite depth corresponding to different sward height) and corresponding nutritional quality (protein above; neutral detergent fiber, below) of bites taken at various sward depth (\% of the maximum sward height). The lower limits of the average bite depth in all seasons were $13.7-14.3 \%$ dietary protein.

follows: (DGH) GH $=3.31( \pm 0.29)+1.95( \pm 0.07) \mathrm{DRH}\left(r^{2}=0.86\right)$ and $\mathrm{BH}=0.081( \pm 0.14)+1.18( \pm 0.04) \mathrm{DRH}\left(r^{2}=0.92\right)$. In summer, wapiti shifted from a solely grass diet to a mixed grass and dicot diet. Nietfeld (1983) reported that dandelions accounted for $18 \%$ of the diet of wapiti in late May and $36 \%$ in June.

Yearlings and sub-adults had different bite sizes in seasonal swards (Fig. 3). In spring, yearling and sub-adult animals had larger bites in 30-cm tall swards than in 10-cm tall swards $(p<0.05)$, whereas in summer they took smaller bites in $30-\mathrm{cm}$ tall swards than in 10-cm tall swards $(p<0.05)$. In autumn, yearlings had smaller bites in swards $>20-\mathrm{cm}$ high than in $10-\mathrm{cm}$ tall swards $(p<0.05$ ), whereas sub-adults had bites of $0.25 \mathrm{~g}$ in $10-\mathrm{cm}$ tall swards and bites of about $0.1 \mathrm{~g}$ across all swards taller than $20 \mathrm{~cm}$ $(p<0.05)$. In autumn, the bite size of yearlings decreased as sward height increased. Bite size for sub-adults was $0.15 \mathrm{~g}$ in $10-\mathrm{cm}$ tall swards, $0.12 \mathrm{~g}$ in $20-30-\mathrm{cm}$ tall swards and $0.13 \mathrm{~g}$ in $40-\mathrm{cm}$ tall swards.

In 6 experiments, 1 tame wapiti ate $0.28 \pm 0.06 \mathrm{~g}$ ( 3 bites) and another ate $0.18 \pm 0.03 \mathrm{~g}$ ( 3 bites) on sod pieces with plant heights of $11.2 \pm 1.2 \mathrm{~cm}$. The predicted bite size for this sward was $0.25 \mathrm{~g}$ with $0.13 \mathrm{~g}$ and $0.51 \mathrm{~g}$ as the $95 \%$ confidence limits. These results were within the range of predicted bite sizes. 


\section{Bite Depth and Diet Quality}

The expected dietary protein and NDF are summarized in Figure 4. In spring, as the bite depth increased from the surface to the bottom of sward, calculated dietary protein in diet decreased and NDF increased. In summer, dietary protein increased as bite depth increased to $60 \%$ of the sward height. Beyond this point, dietary protein decreased, but NDF only increased slightly. In autumn, dietary protein remain relatively constant until wapiti cropped about half of the sward height. We noted a decrease in dietary protein when wapiti cropped more than $60 \%$ of the sward height. Dietary NDF increased in autumn as bite depth and slightly decreased because of short forbs in the swards in summer and autumn.

The average bite depth stratum of wapiti shifted upward in swards from spring to autumn (Fig. 4). Sub-adults grazed deeper in spring swards and they elevated their bite strata in summer and autumn swards. However, the actual bite strata provided higher dietary protein than other cropping heights in summer and autumn. The lower limits of bite depth were adjusted to provide about $14 \%$ dietary protein in all seasons.

\section{Discussion}

\section{Sward Structure}

Hodgson (1981) noted the importance of sward structure in foraging selectivity of domestic grazers and adopted a point quadrat to study the vertical sward profile. On Serengeti grasslands, Coughenour et al. (1984) assessed canopy structure by measuring leaf angle, biomass concentration, and tiller heights. Because of the dense tillers and leaves in our study area, leaf angle measurement was inappropriate and we developed the cubic sampling quadrat to quantify sward structure. Except in swards less than 5-cm tall, the cubic quadrat sampling appeared suitable. The profile we obtained was similar to the triangle shape obtained by Hodgson (1981) using a point quadrat and that by Stobbs (1973b) with a hedge trimmer mounted on an adjustable frame. Biomass and height expressed in relative scales facilitated calculation of bite size and comparisons among seasons.

Milne et al. (1982) noted the linear relationship between bite depth and sward height allows the prediction of forage intake. Bite depth of wapiti in seasonal swards was very similar to those of sheep and cattle (Milne et al. 1982, Barthram and Grant 1984). Grazers tend to bite a fairly constant proportion of total sward height, because they select tillers with greater leaf length and younger laminae. Barthram and Grant (1984) noticed that reduction of bite depth in tall swards may limit intake per bite and consequently total intake. In tall matured swards, wapiti took smaller bites than in short swards during summer and autumn.

\section{Foraging modes}

Wapiti selected forages along horizontal and vertical vectors. Bite depth represents the vertical dimension. In spring, wapiti completely relied on grasses. When green leaves dominated the sward canopy, dried grasses at the bottom of the sward constrained diet selection. Wapiti maximized bite depth by grazing green leaves above dried grasses. In summer and autumn, wapiti preferred short swards with new leaves to tall mature ones. Grass leaves appear more slowly in tall swards and take longer to complete their expansion (Parsons et al. 1991), so grazing can improve pasture quality.

Wapiti selected individual forbs in the horizontal dimension. In early summer dandelion accounted for $20 \%$ of the total pasture biomass (Nietfeld 1983) and wapiti shifted their diet from solely grasses to both dandelion and grasses. Pasture became heterogeneous as seed ripened in autumn, wapiti normally nibbled the leaves, avoided tall reproductive culms, and selected feeding sta- tions with short grasses. The horizontal selection in autumn differed from that in summer: the former involved a selection of feeding stations whereas the latter involved selection of individual plants.

\section{Bite size}

Bite sizes of sub-adults calculated in this study were in the range of bite sizes measured by other methods with the same wapiti. Jiang and Hudson (1992) reported wapiti had average bites of 0.35 \pm 0.08 to $0.41 \pm 0.10 \mathrm{~g}$ in later spring, compared to 0.13 to $0.51 \mathrm{~g}$ in this study. Wilmshurst (1992) measured bite sizes of yearling wapiti as 0.05 to $0.4 \mathrm{~g}$ in sod experiments at the same research site.

Bite size is determined by bite dimensions and sward bulk density. Laca et al. (1992) found that bite area increased with sward height and decreased with bulk density in homogeneous swards. Whether this is true for wapiti needs to be tested, because wapiti and cattle differ in foraging mechanism. Wapiti graze by using their lips, dental pad and lower incisors to grasp, and break the forage instead of using their tongues to sweep and prehend forage. Furthermore, tiller density did not vary greatly in our study area, so we assumed that bite area was constant within seasons.

The relationship between bite size and sward height varies with pasture maturity, plant species composition, and grazing system. On homogeneous artificial pastures, animals graze deeper (Milne 1991) and take larger bites from tall swards than short swards (Burlison et al. 1991). On heterogeneous natural grassland, grazing animals take smaller bites in mature than young swards (Van Soest 1982, Stobbs 1973a). In our study, sub-adult wapiti took larger bites in tall swards in spring than in summer, since the green material in spring swards was homogeneous and highly digestible (Jiang and Hudson 1992). As swards matured, wapiti spent more time in short swards, perhaps due to larger bites and high quality of the newly generated leaves. In summer and autumn, wapiti did not crop as deep as they did in tall spring swards, but their bite depth maximized possible dietary protein. Vertical selection is a balance of the tradeoff between dietary protein and bite size. Sacrifice of bite size in summer and autumn might be compensated by diet quality.

There are limitations in our methodology. First, the method of calculating bite size may be more suitable for swards of intermediate heights. In swards less than 5-cm tall, wapiti may prehend and break the grasses at ground level and bite depth may be difficult to measure. Bite depth is only an indicator of average length of tiller removed (Laca et al. 1992). In such a case, treating the bite volume as a cylinder plus a hemisphere may be better. Another shortcoming of Equation 3 may arise when wapiti adjust the angle of mouth to select the leaf stratum in matured swards, but we did not observe this foraging posture frequently. However, the equations provide a theoretical framework although relationships between bite size and sward height may differ due to different sward structures and foraging responses of the grazer.

Our approach integrated bite depth, sward height, and biomass density to predict bite sizes and diet quality of wapiti in different seasons, depicited the foraging responses of wapiti to sward structure, and provided another avenue to study bite sizes and diet selection of grazing herbivores. As a functional response to sward structure, wapiti may select bite depth and bite site according to the distribution of food items, forage quality and sward configuration. Consequently, bite sizes of wapiti may change markedly in response to seasonal changes in sward structure and forage quality.

\section{Literature Cited}

A.0.A.C. (Association of Official Agricultural Chemists). 1984. Official methods in analysis, 14th. Assoc. of Official Agr. Chem., Washington, D.C. 
Allen, W.G. and I.A. McD. Whittaker. 1970. The determinants of herage intake by grazing sheep: the interrelationship of factors influencing herbage intake and availability. Aust. J. Agr. Res. 21:755-766.

Arnold, G.W. 1987. Influence of the biomass, botanical composition and sward height of annual pastures on foraging behavior by sheep. J. Appl. Ecol. 24:759-772.

Barthram, G.T., and S.A. Grant. 1984. Defoliation of ryegrass-dominated swards by sheep. Grass Forage Sci. 39:211-219.

Black, J.L., and P.A. Kenney. 1984. Factors affecting diet selection of sheep. II. Height and density of pasture. Aust. J. Agr. Res. 35:565-578.

Burlison, A.J., J. Hodgson, and A.W. Illius. 1991. Sward canopy structure and bite dimensions and bite weight of grazing sheep. Grass Forage Sci. 46:29-38.

Coughenour, M.B., S.J. McNaughton, and L.L. Wallace. 1984. Simulation study of East African perennial graminoids responses to defoliation. Ecol. Model. 26:177-201.

Demment, M.W., and G.B. Greenwood. 1990. Forage ingestion: effects of sward characteristics and body size. J. Anim. Sci. 66:2380-2392.

Dudzinskl, M.L., and G.W. Amold. 1973. Comparisons of diets of sheep and cattle grazing together on sown pasture on the southern tablelands of new south Wales by components analysis. Austr. J. Agr. Res. 24:899-912.

Forbes, T.D.A. 1989. Researching the plant-animal interface: the investigation of ingestive behavior in grazing animals. J. Anim. Sci. 66:2369-2379.

Gates, C.C., and R.J. Hudson. 1983. Foraging behavior of wapiti in a boreal forest enclosure. Nat. Can. 110:197-206.

Goering, H.K. and P.J. Van Soest. 1970. Forage fiber analyses (Apparatus, reagents, procedures and some applications). USDA, Agr. Handb. 379.

Hodgson, J. 1981. Variation in surface characteristics of sward and the short-term rate of herbage intake by calves and lambs. Grass Forage Sci. 36:49-57.

Holleman, D.F., and R.G. White. 1989. Determination of digesta fill and passage rate from nonabsorable particulate phase markers using the single dosing method. Can. J. Zool. 67:488-497.

Hudson, R.J., and M.T. Nietfeld. 1985. Effect of forage depletion on feeding rate of wapiti. J. Range Manage. 38:80-82.

Hudson, R.J., and W.G. Watkins. 1986. Foraging rates of wapiti on green and cured pasture. Can. J. Zool. 64:1705-1708.

Jiang, Z., and R.J. Hudson. 1993. Foraging postures of wapiti (Cervus elaphus). Appl. Anim. Behav. Sci. 39:275-288.

Jiang, Z. and R.J. Hudson. 1992. Estimating forage intakes and energy requirements of free-ranging wapiti (Cervus elaphus). Can. J. Zool. 70:675-679.
Jiang, Z., and W. Xia. 1987. Ecological niches of yak. Tibetan sheep and plateau pika in alpine ecosystem. Acta Biologia Plateau Sinica 6 , 115-146.

Laca, E.A., E.D. Ungar, N. Seligman, and M.W. Demment. 1992. Effects of sward height and bulk density on bite dimensions of cattle grazing homogeneous swards. Grass Forage Sci. 47:91-102.

Milne, J.A. 1991. Diet selection by grazing animals. Proc. Nutr. Soc. $50: 77-85$.

Milne, J.A., J. Hodgson, R. Thompson, W.G. Souter, and G.T. Batthram. 1982. The diet ingested by sheep grazing swards differing in white clover and perennial ryegrass content. Grass Forage Sci. 37:209-218.

Nietfield, M.T. 1983. Foraging behavior of wapiti in the boreal mixedwood forest, central Alberta, MSc. Thesis, Univ. Alberta, Edmonton, Canada.

Parsons, A.J., A. Harvey, and J. Woledge. 1991. Plant-animal interactions in a continuously grazed mixture. II. The role of differences in the physiology of plant growth and of selective grazing on the performance and stability of species in a mixture. J. Appl. Ecol. 28:635-658.

Sokal, R.R., and F.J. Rohlf. 1981. Biometry (2nd ed.) pp. 421-423 and p. 509. W.H. Freeman and Co., N.Y.

Spalinger, D.E., T.A. Hanley, and C.T. Robbins. 1988. Analysis of functional response in foraging in the sitka black-tailed deer. Ecol. 69:1166-1173.

Stobbs, T.H. 1973a. The effects of plant structure on the intake of tropical pasture. I. Variation in the bite size of grazing cattle. Austr. J. Agr. Res. 24:809-819.

Stobbs, T.H. 1973b. The effects of plant structure on the intake of tropical pasture. II. Differences in sward structure, nutritive value, and bite size of animals grazing Setaria anceps and Chloris gayana at various stages. Austr. J. Agr. Res. 24:821-829.

Ungar, E.D., and I. Noy-Meir. 1988. Herbage intake in relation to availability and sward structure: grazing process and optimal foraging. $J$. Appl. Ecol. 25:1045-1062.

Ungar, E.D., A. Geniai, and M.W. Demment. 1991. Bite dimensions and herbage intake by cattle grazing short hand-constructed swards. J. Agron. 83:973-978.

Van Soest, P.J. 1982. Nutritional ecology of the ruminant. O \& B, Corvallis, Ore.

Wilmshurst, J.F. 1992. Forage quality and patch choice of wapiti (Cervus elaphus). MSc. Thesis, Univ. Guelph, Canada.

Wonders, W.C. 1969. Atlas of Alberta. Government of Alberta and University of Alberta, Edmonton, Canada. 